\title{
THE RELATIONSHIP BETWEEN LEARNING STYLE AND ANXIETY AMONG JAPANESE UNDERGRADUATES
}

\author{
Michiko Toyama, \& Yoshitaka Yamazaki \\ Department of Business Administration, Bunkyo University (Japan)
}

\begin{abstract}
This study examined the relationship between learning style and anxiety among university freshmen, controlling for gender. Although many studies on learning style have been conducted since the 1960s, relatively little research has highlighted an association between learning style and anxiety. Particularly, there is limited information on how learning style relates to anxiety at a time when students experience the important transition from high school to university. This study sought to fill this gap.

Participants of the study consisted of 194 freshmen of a Japanese university located near Tokyo. The third version of Kolb's Learning Style Inventory was used to identify students' learning style, while the State-Trait Anxiety Inventory (STAI) developed by Spielberger was employed to examine the level of state and trait anxiety. Data were collected in a required course and analyzed using two-way analysis of variance (i.e., learning style and gender). In our sample, 71 students had an Accommodating learning style; 69, Diverging; 41, Assimilating; and 13, Converging. Thus, as a whole, Japanese freshmen were more inclined towards a feeling than a thinking learning orientation. The study included 143 men and 51 women.

Analysis of variance results revealed that the four learning styles significantly differed in both state and trait anxiety variables. However, there was an insignificant difference in both anxiety types between male and female students. Additionally, there was no interaction effect of learning style and gender in terms of both types of anxiety. The Tukey post hoc test showed that the Diverging learning style had a significantly higher level of state anxiety than the Accommodating style and Converging style. Also, the Diverging style had a significantly higher level of trait anxiety than the Accommodating style and a marginally higher level than the Converging style. These results suggest that regardless of gender, freshmen with a Diverging learning style, compared with other learning styles, tend to have the highest level of state and trait anxiety during this important academic transition.
\end{abstract}

Keywords: Learning style, state anxiety, trait anxiety, Japanese undergraduate students.

\section{Introduction}

Freshmen encounter psychological challenges when beginning their university life (Basco \& Olea, 2013; Clinciu, 2013; Pancer, Hunsberger, Pratt, \& Alisat, 2000). One such challenge, student anxiety as a negative emotional experience derived from the unfamiliar university environment, leads to adverse consequences (Von Ah, Ebert, Ngamvitroj, Park, \& Kang, 2004) such as poor academic adjustment and performance (Levitz \& Noel, 1989; Saklofske, Austin, Mastoras, Beaton, \& Osborne, 2012), mental and physical illness (Boery et al., 2017), and even dropout (Clinciu, 2013). Research on efforts to alleviate freshman anxiety has reported the effectiveness of social support (Compas, Wagner, Slavin, \& Vannatta, 1986; Sato et al., 2017), which includes institutional aids and school counselors. Although the effect of freshman anxiety as well as methods to reduce it have been investigated, little research has examined the relationship between freshman anxiety and individual differences-especially learning style. Using a sample of university students in Jordan, Kadiem and Hamzah (2004) documented the association of gender, personality, and trait-anxiety with learning styles, but their study did not highlight the context of transition to university. Based on studies performed by Spielberger (1972) and colleagues (Spielberger, Gorsuch, Lushene, Vagg, \& Jacobs, 1983; Vagg, Spielberger, \& O'Hearns, 1980), state anxiety was also identified as a crucial construct that hinges more on environmental conditions. As a consequence of the limited research, it is still unknown whether there is a relationship between learning style and state as well as trait anxiety of university freshmen. Accordingly, the aim of this study was to examine how learning style relates to state and trait anxiety in this group. 


\section{Literature review}

\subsection{Learning style}

Over several decades, learning style has been of interest to scholars and practitioners in multiple fields (Honigsfeld \& Schiering, 2004). A large number of learning style studies have indicated that people have a distinctive way of learning (Dunn \& Dunn, 1978; Kolb, 1984; Kolb \& Kolb, 2017; Peterson, Rayner, \& Armstrong, 2009). The term "learning style" refers to a person's preferred way of responding to tasks, assignments, or problems in a learning situation (Peterson et al., 2009). This study chose Kolb's (1984) learning model because it is based on individuals' experiences as a source of learning, and in this study the learning context involved freshmen experiencing an academic transition.

According to Kolb's (1984) model, learning has four modes: concrete experience (CE), reflective observation (RO), abstract conceptualization (AC), and active experimentation (AE). The $\mathrm{CE}$ learning mode is dialectically opposed to the $\mathrm{AC}$ mode in the grasping experience dimension, while the $\mathrm{RO}$ learning mode is dialectically contrasted with the $\mathrm{AE}$ mode in the transforming experience dimension. A combination of two learning modes from each learning dimension creates four basic learning styles. The Diverging learning style consists of the $\mathrm{CE}$ and $\mathrm{RO}$ modes and is characterized by the competencies of understanding people, having strong interpersonal relationships, and being imaginative and patient. The Assimilating learning style, made up of the AC and RO modes, relates to the characteristics of making ideal plans, building theories and models, and viewing things from various perspectives. The Converging learning style is composed of the $\mathrm{AC}$ and $\mathrm{AE}$ modes; it has the features of solving problems practically, making decisions, and establishing pragmatic goals. Finally, the Accommodating learning style, with the $\mathrm{CE}$ and $\mathrm{AE}$ modes, is characterized by a trial-and-error approach, motivating and leading people, and making things happen.

\subsection{State and trait anxiety}

Anxiety refers to an unpleasant emotion such as apprehension and worry (Kazdin, 2000). Spielberger (2013) indicated that the term "anxiety" has been used to describe not only certain types of emotions but also diverse cognitive actions or processes. He argued that anxiety is exhibited in two dimensions: state and trait anxiety (Spielberger, 2013). State anxiety involves a transitory excitement in a short-term condition based on a specific situation; thus, it is thought that the change of situation affects its occurrence. Trait anxiety is characterized as a relatively stable and acquisitive attitude; thus, it is recognized as a personality trait. It tends to make people see a broad scope of safe conditions as dangerous (Nazerian, Zamani, \& Soltani, 2011).

\section{Methods}

This study was part of a project that explored multiple features of freshmen in a Japanese university located near Tokyo. To collect data for the study, one of the authors asked four instructors who taught a course required for freshmen in the management department to distribute paper-based surveys in their classes at the beginning of the semester. There were 194 participants, 143 men and 51 women. To examine state and trait anxiety, this study employed the State-Trait Anxiety Inventory (STAI) designed by Spielberger. STAI questions have a 4-point Likert-type scale, ranging from 1, not at all, to 4, very much so. For this sample, the Cronbach's alpha was 0.86 for the STAI state scale and 0.84 for the STAI trait scale. The third version of Kolb's Learning Style Inventory (Kolb, 1999) was applied to investigate freshmen's learning style. Research has shown that the third version has better reliability than previous versions (Kayes, 2005). In this sample, 71 students had an Accommodating learning style (37\%); 69, Diverging (36\%); 41, Assimilating (21\%); and 13, Converging (8\%). Accordingly, as a whole, Japanese freshmen exhibited a preference for a feeling (CE) rather than a thinking (AC) learning orientation. Most Japanese freshmen had an Accommodating or Diverging learning style, which is consistent with past learning style study results (Toyama \& Yamazaki, 2018; Yamazaki, Toyama, \& Attrapreyangkul, 2018). To analyze how freshmen's learning style related to their state and trait anxiety, this study used two-way analysis of variance (i.e., learning style and gender) by controlling gender.

\section{Results}

Results of two-way analysis of variance illustrated significant differences among the four learning styles in terms of state anxiety $(\mathrm{F}=3.38, p<0.05)$ and trait anxiety $(\mathrm{F}=4.07, p<0.01)$; however, gender did not have a significant relationship with the two anxiety variables (state: $\mathrm{F}=0.22$, $p>0.05$; trait: $\mathrm{F}=1.38, p>0.05$ ). Additionally, there was no interaction effect of learning style and gender in terms of anxiety. Based on the Tukey post hoc test, the Diverging learning style had a 
significantly higher level of state anxiety than the Accommodating style $(p<0.01)$ and Converging style $(p<0.05)$. Also, the Diverging style had a significantly higher level of trait anxiety than the Accommodating style $(p<0.01)$ and a marginally higher level than the Converging style $(p<0.10)$. These results indicated that regardless of gender, freshmen with a Diverging learning style, compared with other learning styles, were likely to have the highest level of state and trait anxiety during their academic transition. Furthermore, freshmen who preferred to learn through active experimentation (AE), which represents the common learning mode of the Converging and Accommodating styles, tended to exhibit a lower level of state and trait anxiety when beginning their university studies. Table 1 summarizes results of two-way analysis of variance and the Tukey post hoc test, and Figure 1 shows state and trait anxiety levels according to learning style and gender.

Table 1. Results of two-way analysis of variance with the Tukey test.

\begin{tabular}{|c|c|c|c|c|c|c|c|c|c|c|c|c|c|}
\hline \multirow[b]{2}{*}{ Source } & & \multicolumn{6}{|c|}{ State anxiety } & \multicolumn{6}{|c|}{ Trait anxiety } \\
\hline & & $S S$ & $d f$ & $M S$ & $F$ & $\eta^{2}$ & & $S S$ & $d f$ & $M S$ & $F$ & $\eta^{2}$ & \\
\hline Learning style & & 2.02 & 3 & 0.67 & $3.38 *$ & 0.05 & & 2.39 & 3 & 0.80 & $4.07 * *$ & 0.06 & \\
\hline Gender & & 0.04 & 1 & 0.04 & 0.22 & 0.00 & & 0.27 & 1 & 0.27 & 1.38 & 0.01 & \\
\hline \multicolumn{2}{|l|}{ Learning style x Gender } & 0.22 & 3 & 0.07 & 0.37 & 0.01 & & 0.39 & 3 & 0.13 & 0.67 & 0.01 & \\
\hline & & & & \multicolumn{4}{|c|}{ Mean Differences } & & & \multicolumn{4}{|c|}{ Mean Differences } \\
\hline Learning style group & $\mathrm{n}$ & Mean & $S D$ & 1 & 2 & 3 & 4 & Mean & $S D$ & 1 & 2 & 3 & 4 \\
\hline 1.Diverging & 69 & 2.45 & 0.43 & 0.00 & & & & 2.66 & 0.39 & 0.00 & & & \\
\hline 2. Assimilating & 41 & 2.36 & 0.41 & 0.09 & 0.00 & & & 2.60 & 0.46 & 0.06 & 0.00 & & \\
\hline 3. Converging & 13 & 2.08 & 0.41 & $0.37^{*}$ & 0.28 & 0.00 & & 2.35 & 0.39 & $0.32^{\dagger}$ & 0.25 & 0.00 & \\
\hline \multirow[t]{2}{*}{ 4. Accommodating } & 71 & 2.19 & 0.47 & $0.26^{* *}$ & 0.17 & -0.11 & 0.00 & 2.41 & 0.48 & $0.26^{*}$ & 0.19 & -0.06 & 0.00 \\
\hline & & & & \multicolumn{2}{|c|}{ Mean Differences } & & & & & \multicolumn{2}{|c|}{ Mean Differences } & & \\
\hline Gender group & $\mathrm{n}$ & Mean & $S D$ & 1 & 2 & & & Mean & $S D$ & 1 & 2 & & \\
\hline 1. Male & 143 & 2.30 & 0.47 & 0.00 & & & & 2.52 & 0.46 & 0.00 & & & \\
\hline 2. Female & 51 & 2.33 & 0.42 & 0.03 & 0.00 & & & 2.58 & 0.42 & 0.06 & 0.00 & & \\
\hline
\end{tabular}

${ }^{* * *} p<0.01,{ }^{*} p<0.05,{ }^{\dagger} p<0.10$.

Figure 1. State and trait anxiety levels according to learning style and gender.
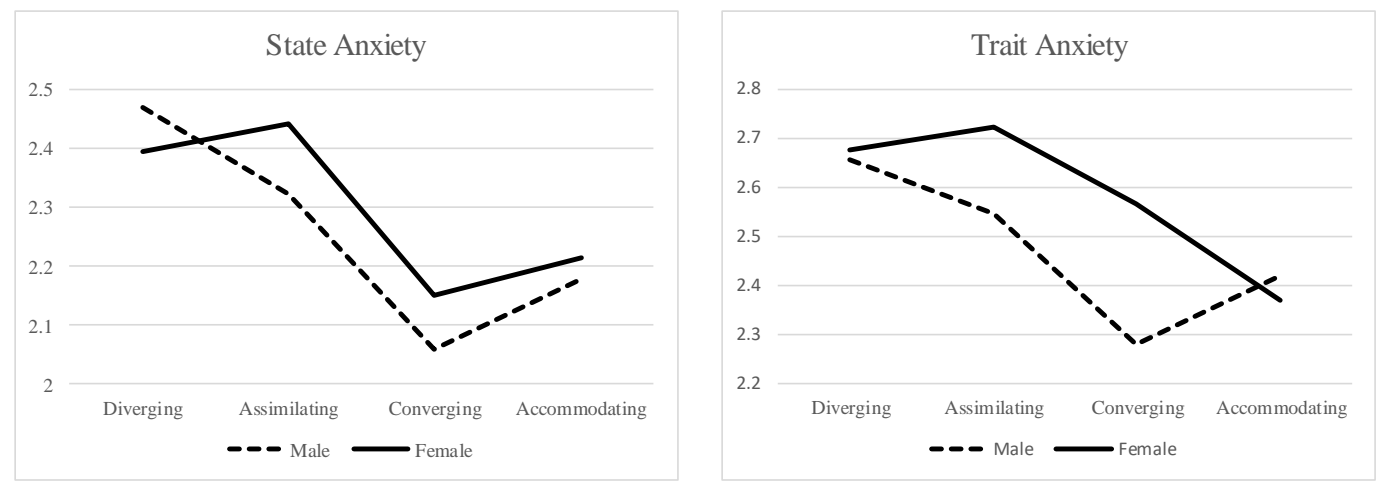

\section{Discussion}

This study showed a strong relationship between learning style and state-trait anxiety among university freshmen. Although several previous studies on learning style did not focus on freshmen (Ayalp \& Özdemir, 2016; Kadiem \& Hamzah, 2004; Yazici, 2017), their results are partly congruent with our results. For example, Ayalp and Özdemir (2016) reported a significant association between learning style and test anxiety using a sample from Turkish universities. More specifically, Turkish students with a Diverging learning style had a higher level of test anxiety than those with a Converging learning style. The other two studies applied different measures for learning style, which do not allow for direct comparisons. However, it should be noted that they showed that learning style was relevant to trait anxiety (Kadiem \& Hamzah, 2004) and text anxiety (Yazici, 2017). 
An interesting question is raised in terms of why the Diverging learning style relates to a higher level of state and trait anxiety. As those who learn through a Diverging learning style use the two modes of concrete experience (CE) and reflective observation (RO), they are sensitive to their internal and external environments. If they face a situational, unfamiliar problem, they may find it challenging to quickly resolve the problem or make decisions to cope with it. These activities require action rather than reflection. Thus, characteristics of learning style seem to be related to the anxiety. Furthermore, the learning tendencies of the Diverging learning style may hinder self-confidence development, which is thought to reduce anxiety. A recent study by Yamazaki, Toyama, and Ubed (2018) using a sample of Indonesian managers documented that abstract conceptualization (AC) over concrete experience (CE), and active experimentation (AE) over reflective observation (R), were associated with self-efficacy beliefs. In other words, people with a Diverging learning style have a lower level of self-efficacy than those with a Converging learning style. In the area of sport study, Nazerian et al. (2011) found a relationship between state and trait anxiety and self-confidence; thus, a future study should explore how learning style, anxiety, and self-confidence are interrelated.

As a practical implication, educational institutions and university teachers may want to pay special attention to freshmen with a Diverging learning style, who tend to have a higher level of state and trait anxiety. Since there is matching between the Diverging learning style and the Facilitator educator role (Kolb \& Kolb, 2017), if university teachers employ a warm, friendly, and interpersonal approach to Diverging-style freshmen, their anxiety level may be decreased. These actions may also increase students' motivation to learn (Toyama \& Yamazaki, 2019).

\section{References}

Ayalp, G. G., \& Özdemir, N. (2016). Relationship between test anxiety and learning styles of architecture undergraduates. Creative Education, 7(2), 364-375. doi:10.4236/ce.2016.72036

Basco, R. E., \& Olea, M. T. (2013). Correlation between anxiety level and academic performance of BS biology freshmen students. International Journal of Educational Research and Technology, 4(1), 97-103.

Boery, E. N., Casotti, C. A., Freire, I. V., Pereira, R., de Oliveira, B. G., \& Ribeiro, Í. J. S. (2017). Stress and quality of life among university students: A systematic literature review. Health Professions Education, 4(2), 70-77. doi:10.1016/j.hpe.2017.03.002

Clinciu, A. I. (2013). Adaptation and stress for the first year university students. Procedia - Social and Behavioral Sciences, 78, 718-722. doi:10.1016/j.sbspro.2013.04.382

Compas, B. E., Wagner, B. M., Slavin, L. A., \& Vannatta, K. (1986). A prospective study of life events, social support, and psychological symptomology during the transition from high school to college. American Journal of Community Psychology, 14, 241-257.

Dunn, R., \& Dunn, K. (1978). Teaching students though their individual learning styles: A practical approach. Upper Saddle River, NJ: Prentice-Hall.

Honigsfeld, A., \& Schiering, M. (2004). Diverse approaches to the diversity of learning styles in teacher education. Educational Psychology, 24(4), 447-507.

Kadiem, S., \& Hamzah, M. D. (2004). The influence of sex, personality types and trait-anxiety of learning styles among university students in Jordan. Journal Pendidik dan Pendidikan, 19, 97-106.

Kayes, D. C. (2005). Internal validity and reliability of Kolb's Learning Style Inventory version 3 (1999). Journal of Business and Psychology, 20(2), 249-257.

Kazdin, A. E. (2000). Encyclopedia of psychology, Vol. 1, 8th ed. Washington, DC: American Psychological Association.

Kolb, A. Y., \& Kolb, D. A. (2017). The experiential educator: Principles and practices of experiential learning. Kaunakakai, HI: EBLS Press.

Kolb, D. A. (1984). Experiential learning: Experience as a source of learning and development. Englewood Cliffs, NJ: Prentice-Hall.

Kolb, D. A. (1999). Learning Style Inventory, Version 3. Boston, MA: TRG Hay/McBer.

Levitz, R., \& Noel, L. (1989). Connecting students to institutions: Keys to retention and success. In M. L. Upcraft, J. N. Gardner, \& Associates (Eds.), The freshman year experience: Helping students survive and succeed in college (pp. 65-81). San Francisco, CA: Jossey-Bass.

Nazerian, I., Zamani, A., \& Soltani, A. (2011). The comparison of trait anxiety, state anxiety, and self-confidence among male athletes of team sports and individual sports in the country. Journal of Physical Education and Sport Science, 3, 3. Retrieved from https://pdfs.semanticscholar.org/078e/ 4ef93269b8d6f8aaaa23e2b1e339396b06a0.pdf 
Pancer, S. M., Hunsberger, B., Pratt, M. W., \& Alisat, S. (2000). Cognitive complexity of expectations and adjustment to university in the first year. Journal of Adolescent Research, 15(1), 38-57. doi: $10.1177 / 0743558400151003$

Peterson, E., Rayner, S. G., \& Armstrong, S. J. (2009). Researching the psychology of cognitive style and learning style: Is there really a future? Learning and Individual Differences, 19(4), 518-523.

Saklofske, D. H., Austin, E. J., Mastoras, S. M., Beaton, L., \& Osborne, S. E. (2012). Relationships of personality, affect, emotional intelligence and coping with student stress and academic success: Different patterns of association for stress and success. Learning and Individual Differences, 22(2), 251-257. doi:10.1016/j.lindif.2011.02.010

Sato, S., Suzuki, T., Kawashiri, T., Yamaguchi, M., Murata, T., \& Unemoto, S. (2017). Characteristics in mental health and stress coping behaviors of the university freshmen who are unwilling to join the university and who feel anxiety about academic learning. KIT Progress, 25, 47-56.

Spielberger, C. D. (1972). Anxiety as an emotional state. In C. D. Sprielberger (Ed.), Anxiety: Current trends in theory and research (pp. 23-49). New York, NY: Academic Press.

Spielberger, C. D. (2013). Theory and research on anxiety. In C. D. Spielberger (Ed.), Anxiety and behavior (pp. 3-20). New York, NY: Academic Press.

Spielberger, C. D., Gorsuch, R. L., Lushene, R. E., Vagg, P. R., \& Jacobs, G. A. (1983). Manual for the State-Trait Anxiety Inventory. Palo Alto, CA: Counseling Psychologist Press.

Toyama, M., \& Yamazaki, Y. (2018). A cross-cultural comparison of learning style and self-efficacy between employees in Japan and Indonesia. International Journal of Education, Psychology and Counselling, 3(13), 44-56.

Toyama, M., \& Yamazaki, Y. (2019). Are there effects of a match between learning style and teaching style in an EFL classroom? Innovation in Language Learning and Teaching (online version), 1-16. doi:10.1080/17501229.2019.1575386

Vagg, P. R., Spielberger, C. D., \& O'Hearns, T. P. (1980). Is the State-Trait Anxiety Inventory multidimensional? Personality and Individual Differences, 1, 207-214.

Von Ah, D., Ebert, S., Ngamvitroj, A., Park, N., \& Kang, D. (2004). Predictors of health behaviours in college students. Journal of Advanced Nursing, 48(5), 463-474.

Yamazaki, Y., Toyama, M., \& Attrapreyangkul, T. (2018). Cross-cultural differences in learning style and learning skills: A comparison of Japan, Thailand, and the USA. In C. Maheshkar \& V. Sharma (Eds.), The handbook of research on cross-cultural business education (pp. 160-182). New York, NY: IGI Global.

Yamazaki, Y., Toyama, M., \& Ubed, R. S. (2018). Exploring how learning style relates to general and career management self-efficacy beliefs in a managerial context. Organization Management Journal, 15(4), 201-213. doi:10.1080/15416518.2018.1528859

Yazic1, K. (2017). The relationship between learning style, test anxiety and academic achievement. Universal Journal of Educational Research, 5(1), 61-71. doi:10.13189/ujer.2017.050108 